\title{
PARASITOLOGICAL AND SEROLOGICAL STUDIES ON AMOEBIASIS AND OTHER INTESTINAL PARASITIC INFECTIONS IN RECIFE AND ITS SUBURBAN AREA, NORTHEAST BRAZIL
}

\author{
Mitsu OKAZAKI (1), Masaichi OKAZAKI (1), Paulo MirANDA (2), Joan NEto (3), Vilneide DIEgUES (3), \\ Joan ALVES (3), Machado CAUAS (3), Masanobu TANABE $(2,4)$, Seíki KOBAYASHI $(2,4)$ \\ Nobuaki KANEKO $(2,4)$, Kouichi NAGAKURA $(2,5)$, Masashi KOBAYASHI $(2,6)$, Severa MOTTA $(2,4,7)$, Seiki
} TATENO $(2,4)$ \& Tsutomu TAKEUCHI (4).

\section{S U $\quad \mathbf{M} \quad \mathbf{M} \quad \mathbf{A} \quad \mathbf{R} \quad \mathbf{Y}$}

Parasitological examinations were carried out during April to August, 1987, with 187 out-patients of the IMIP hospital, located in the center of Recife City, and 464 inhabitants of several villages around Cabo City, $50 \mathrm{Km}$ southeast of Recife, Pernambuco, Brazil. Approximately $71 \%$ of the IMIP patients and $92 \%$ of the Cabo inhabitants were infected with at least one species of intestinal parasite. There was minimum difference in the prevalence rate of Trichuris trichiura between two areas, whereas the prevalence rates of Ascaris lumbricoides, hookworms, Strongyloides stercoralis, Schistosoma mansoni and Entamoeba histolytica were higher in the inhabitants of the Cabo City area. Only Giardia lamblia was more prevalent in the out-patients of IMIP hospital. Test tube cultivation revealed that the prevalence rate of Necator americanus in both areas was much higher than that of Ancylostoma duodenale, and also that the prevalence rate of $\mathbf{S}$. stercoralis of the IMIP patients and $\mathrm{Cabo}$ inhabitants were $4.5 \%$ and $9.6 \%$, respectively.

Six hundred and fifteen sera were serologically examined for amoebiasis by the gel diffusion precipitation test (GDP) and enzyme linked immunosorbent assay (ELISA) using the antigen prepared from axenically cultured trophozoite of E. histolytica (strain HM-1:IMSS). No positive reaction was observed in all of the sera as examined by GDP, while 32 out of 615 sera were positive on ELISA.

KEY WORDS: Parasitic helminths; Parasitic protozoa; Amoebiasis; Northeast Brazil; Stool examination; Sero-epidemiology.

\section{INTRODUCTION}

An analysis of the annual statistics on the population in northeast Brazil demonstrated that there has been a high level of infantile mortality. Main causes of this high mortality were

(1) Secretaria de Saúde, Pernambuco, Brazil.

(2) Laboratório de Imunopatologia Prof. Keizo Asami, Universidade Federal de Pernambuco (UFPE), Pernambuco, Brazil.

(3) Hospital of Instituto Materno Infantil de Pernambuco, Pernambuco, Brazil.

(4) Department of Parasitology, School of Medicine, Keio University, Japan.

(5) Department of Parasitology, School of Medicine, Tokai University, Japan

(6) Department of Parasitology, School of Medicine, Chiba University, Japan

(7) Department of Biophysics and Radiobiology, UFPE, Pernambuco, Brasil.

Address for correspondence: Prof. Masanobu Tanabe.

Department of Parasitology, School of Medicine, Keio University.

Shinanomachi 35 , Shinjuku-ku, Tokyo 160, Japan 
OKAZAKI, M: OKAZAKI, M : MIRANDA, P : NETO, J : DIEGUES, V : ALVES. J : CAUAS. M : TANABE M KOBAYA SHI. S.; KANEKO. N. NAGAKURA.K. KOBAYASHI M. MOTTA S. TATENO. S \& TAKEUCHI, T. ParaSIO logical and serological studies on amoebiasis and other intestinal parasitic infections in Recife and its suburban area. Northeast Brazil. Rev. Inst. Med. trop. Sao Paulo 30 (1): 313321.1988.

assumed to be malnutrition and infectious disea ses by bacteria, virus and parasite ${ }^{30}$. Parasitic infections do not necessarily cause serious disease in the human host, but they interfere with the nutritional status and ultimately lead them more susceptible to other diseases. Prevalence rate of parasitic infections can, therefore, be one of the major parameters of local public health of the inhabitants anywhere.

The prevalence of Entamoeba histolytica in developing countries is often assumed to be high, frequently without supporting data. Major reasons for this may be that proper identification of E. histolytica cyst in stool is difficult without professional experience, and that reliable diag. nosis of amoebiasis is often not attainable by stool examination alone. Now, serologic proce dures have been commonly utilized for the diag. nosis of amoebiasis in many countries because these tests are highly specific and have a sufficient sensitivity ${ }^{9}, 10,13,16.19 .25$. In northeast Brazil. the prevalence of $\mathbf{E}$. histolytica has been estima ted to be high, but the incidence of amoebic liver abscess at autopsy was reported to be very low ${ }^{20}$. Such discrepancies are apparently due to lack in reliable data on the epidemiology and estima tion on annual morbidity by this parasite, since serological examination for amoebiasis is still not common in this area.

Parasitological examination of intestinal helminths and protozoa, and serological exami nation for amoebiasis were carried out during April to August, 1987, in Recife and its suburban area. This report presents the results of these studies as an attempt to define a reliable preva lence rate in intestinal helminths and protozoa, in particular that of amoebiasis in this area

\section{MATERIALS AND METHODS}

From April to August, 1987, the out-patients of the hospital of Instituto Materno Infantil de Pernambuco (IMIP), located in the center of Re. cife, were selected at random (10 to 30 patients per day land their general health conditions were preliminarily checked. On this occasion, age, sex, the place of residence as well as socio-economic state of the family of the patient were recorded, and the peripheral blood was collected. Sera were separated by centrifugation at the Laboratório de Imunopatologia Prof. Keizo
Asami (LIKA), Federal University of Pernam buco. Fresh stools were collected within a couple of days after the first visit. Inhabitants in several villages around Cabo city, located $50 \mathrm{Km}$ sou theast of Recife, also primarily received general medical examination, and their age. sex, medi cal history as well as socio-economic state were recorded. Blood and stools were collected at this time, and sera were separated in LIKA within 4 hours after bleeding.

A single stool specimen collected as above was examined by the direct smear" , by the for malin ether centrifugation technique (MGL me thod $)^{21}$, and by test tube cultivation method ${ }^{8}$ to distinguish filariform larve of hookworms and Strongyloides. Ninety eight stools, including 16 positive stools for E. histolytica cysts, were ino culated into the Balamuth medium ${ }^{3}$ and the tro phozoite grow th were examined after cultivation for 72 hours at $27^{\circ} \mathrm{C}$. All parasitological exami nation of stools were done by a single medical parasitologist, who had sufficient experience on parasitological diagnosis.

The antigen used for serologic test of amoe biasis was prepared by the method of TAKEU. CHI \& KOBAYASHI ${ }^{25}$ from axenic strain of $\mathbf{E}$. histolytica (HM 1:IMSS), cultured in BI-S-33 medium $^{6}$. The lyophilized antigen was dissolved in $20 \mathrm{mM}$ sodium phosphate buffer, $\mathrm{pH}$ 7.2. After stirring for $30 \mathrm{~min}$ under ice cold condition, the solution was centrifuged at $15,000 \mathrm{~g}$ for $30 \mathrm{~min}$ at 4 "C. The supernatant fluid was filtered by Millex-GS filter (Millipore Co. Bedford, MA, USA) at $0.2 \mu \mathrm{m}$ porosity and kept at $-70^{\circ} \mathrm{C}$ until use.

All sera were tested for antibodies to $\mathbf{E}$. histolytica by the gel diffusion precipitation test $(\text { GDP })^{13}$ and enzyme linked immunosorbent as say (ELISA) according to the modified method of MATSUDA et al. ${ }^{15}$. ELISA was performed in 96. well microtiter flat-bottomed plate (NUNC Co. Denmark). The optimum antigen concentration was determined by checker board titration between serial dilution of antigen against posi tive and negative reference sera. Half number of wells in a plate were sensitized with $100 \mu$ l of the antigen prepared as above at concentration of $10 \mu \mathrm{g}$ protein per $\mathrm{ml}$ in $50 \mathrm{mM}$ carbonate buffer, $\mathrm{pH} 8.15$, in a moist chamber at $37^{\circ} \mathrm{C}$ for 2 hours. Non-sensitized wells were filled with $100 \mu \mathrm{l}$ of car 


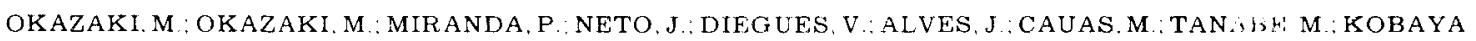
SHI, S; KANEKO, N.: NAGAKURA, K.: KOBAYASHI. M.; MOTTA S.: TATENO, S. \& TAKEUCHI, T. - Parasito logical and serological studies on amoebiasis and other intestinal parasitic infections in Recife and its suburban area, Northeast Brazil. Rev. Inst. Med. trop. Sao Paulo, 30 (4): $313321,1988$.

bonate buffer alone. The plate was washed three times with $150 \mathrm{mM}$ sodium phosphate-buffered saline, $\mathrm{pH} 7.2$, containing $0.05 \%$ Tween 20 (PBS T). After washing the wells, $200 \mu \mathrm{l}$ of PBS/T con taining $2 \%$ bovine serum albumin (BSA, Sigma Chem., St Lois, MO, USA) was added to all wells to block non-specific immunoglobulin binding, and the plate was incubated at $37{ }^{\circ} \mathrm{C}$ for $60 \mathrm{~min}$. After washing the wells with $\mathrm{PBS} / \mathrm{T}$, test sera diluted 200 times with PBS/T containing $1 \%$ BSA were placed in a sensitized and non sen sitized wells and the plate further incubated at $37^{\circ} \mathrm{C}$ for $60 \mathrm{~min}$. After washing with PBS T, 100 $\boldsymbol{\mu l}$ of horseradish peroxidase (HRP) labelled an ti-human IgG rabbit inmunoglobulin (Miles Scientific, Naperville, IL, USA), $10^{4}$-fold diluted, was added and incubation was carried out at $37^{\circ} \mathrm{C}$ for $60 \mathrm{~min}$. After washing the wells 3 times with PBS/T, $200 \mu$ l of the substrate solution, i.e., $30 \mathrm{mg}$ diammonium salt of 2,2'-azino-bis (3-ethyl benzthiazoline-sulfonic acid) (Sigma Chem.) dis solved in a mixture of $100 \mathrm{mM}$ citric acid and $200 \mathrm{mM}$ sodium phosphate dibasic. $\mathrm{pH} 4 . \hat{0}$, with $10 \mu \mathrm{l}$ of $\mathrm{H}_{2} \mathrm{O}_{2}(30 \%)$, was added to each well and then the plate was kept at room temperature for $60 \mathrm{~min}$. Subsequently, the absorbance of reac tion mixture was measured by EIA Reader (Mo del 2550. Bio Rad Lab., Tokyo) at $405 \mathrm{~nm}$. To correct daily variation of absorbance. triplet of positive reference serum (isolated from a Japanese patient with confirmed amoebic liver abscess) were included on each plate, and the corrected absorbance of sample was calculated according to the modified method of VOLLER et $\mathrm{al}^{29}$. as follows. Coefficient value was first calculated by the equation (1), and then the corrected absorbance of sample serum was calculated by multiplying the absorbance of sample serum by the coefficient value according to equation (2).

$$
\begin{aligned}
& \mathrm{a}=1.5 /(\mathrm{Pa}-\mathrm{Pb}) \ldots \ldots \ldots \ldots \ldots \ldots \ldots \ldots \ldots \ldots \ldots \ldots \ldots \ldots \ldots \ldots \ldots \ldots \ldots \ldots \ldots \ldots \ldots \ldots \ldots \ldots \ldots
\end{aligned}
$$

in which

a: the coefficient value

Pa: mean absorbance of positive controls at antigen positive well

$\mathrm{Pb}$ : mean absorbance of positive controls at antigen-free well

Sa: absorbance of sample serum at antigen positive well

$\mathrm{Sb}$ : absorbance of sample serum at antigen free well

\section{Sc: the corrected absorbance of sample se- rum}

Protein concentration was determined by the method of LOWRY et al. ${ }^{12}$, with bovine serum albumin (fraction $V$ ) as a standard.

\section{RESULTS}

Sex, age distribution and socio economic condition of the out-patients of IMIP hospital and the inhabitants in Cabo City area were summarized in Table 1. Virtually all of the IMIP patients were under 9 years old, and only $4 \%$ of them were from 10 to 12 years old. Most of the IMIP patients inhabited in the downtown or ur. ban area of Recife. Approximately one-third of the Cabo inhabitants who took our health examination were under 9 years old, another one-

TABLE

Sex, age distribution and socio economic feature of the out pa.

\begin{tabular}{|c|c|c|c|}
\hline & & $\begin{array}{l}\text { IMIP } \\
\text { patients }\end{array}$ & $\begin{array}{c}\text { Cabo } \\
\text { inhabitants }\end{array}$ \\
\hline Sex & $\begin{array}{c}\text { Male } \\
\text { Female }\end{array}$ & $\begin{array}{r}100(53.5 \%) \\
87(46.5 \%)\end{array}$ & $\begin{array}{l}178(38.4 \%) \\
286(61.6 \%)\end{array}$ \\
\hline Age & $\begin{array}{c}09 \\
10.19 \\
20-39 \\
40 \leq\end{array}$ & $\begin{array}{l}179(96.0 \%) \\
8(4.0 \%) \\
0 \\
0\end{array}$ & $\begin{array}{l}156(33.6 \%) \\
153(33.0 \%) \\
81(17.5 \%) \\
74(15.9 \%)\end{array}$ \\
\hline Occupation & & & $\begin{array}{c}\text { Farm hand } \\
(100 \%)\end{array}$ \\
\hline $\begin{array}{l}\text { Income } \\
\text { (US syear) }\end{array}$ & $\begin{array}{c}0.400 \\
4011000 \\
1.001 \leq\end{array}$ & $\begin{array}{r}127(67.9 \%) \\
53(28.3 \%) \\
7(3.7 \%)\end{array}$ & $\begin{array}{c}464(100 \%) \\
0 \\
0\end{array}$ \\
\hline House & $\begin{array}{l}\text { Wooden } \\
\text { Brick } \\
\text { Apartment }\end{array}$ & $\begin{array}{r}54(28.8 \%) \\
131(70.0 \%) \\
2(1.2 \%)\end{array}$ & $\begin{array}{l}128(27.6 \%) \\
336(72.4 \%) \\
\quad 0\end{array}$ \\
\hline Number of room & $\begin{array}{c}1 \\
23 \\
4 \leq\end{array}$ & $\begin{array}{r}31(16.6 \%) \\
151(80.7 \%) \\
5(2.7 \%)\end{array}$ & $\begin{array}{r}47(10.2 \%) \\
406(87.5 \% \\
11(2.3 \%)\end{array}$ \\
\hline Toilet & $\begin{array}{l}\text { present } \\
\text { absent }\end{array}$ & $\begin{array}{r}142(76.0 \%) \\
45(24.0 \%)\end{array}$ & $\begin{array}{l}293(63.2 \%) \\
171\{36.8 \%)\end{array}$ \\
\hline $\begin{array}{l}\text { Number of } \\
\text { family member }\end{array}$ & $\begin{array}{l}1-3 \\
4-7 \\
8 \leq\end{array}$ & $\begin{array}{r}20(10.8 \%) \\
125(66.9 \%) \\
42(22.3 \%)\end{array}$ & \\
\hline Total & & 187 & 464 \\
\hline
\end{tabular}
tients of IMIP hospital and the inhabitants of Cabo City area

Values in parentheses represent the percentage (\%) of each region 
OKAZAKI, M.: OKAZAKI, M.: MIRANDA. P : NETO J : DIEGUES.V : ALVES.J : CAUAS.M.: TANABI $\quad 1:$ KOBAYA SHI. S.: KANEKO. N.: NAGAKURA. K.: KOBAYASHI. M : MOTTA. S.: TATENO. S. \& TAKEUCHI. T. - PaIaSIT logical and serological studies on amoebiasis and other intestinal parasitic infections in Recife and its suburban area. Northeast Brazil. Rev. Inst. Med. trop. Sảo Paulo, 30 (4): 313321.1988

third were 10 to 19 years old, and the remainder were over 20 years old. All of them inhabited in the several villages located in the rural area around Cabo City and their family members we re employed by the farm of sugar-cane as a farm hand. Also demonstrated in Table 1 was that the social condition of the families of IMIP pa tients and Cabo inhabitants seemed to be low judging from their socio-economic characteristics. There was, however, a little difference in the total amounts of income per year between the families of IMIP patients and Cabo inhabi tants.

Prevalence of intestinal parasites of the IMIP patients and the Cabo inhabitants were summarized in Table 2. Approximately $71.2 \%$ of the IMIP patients and $91.9 \%$ of the Cabo inha bitants were infected with at least one species of intestinal parasite. The lower prevalence of intestinal parasites in the IMIP patients was also found as compared with that of the Cabo inhabi tants utilizing comparable age groups, under 12 years old. There was no significant difference in the prevalence rate between males and females in both groups.

Prevalence of intestinal helminths was sum marized in Table 3 . Trichuris trichiura infec tions, with a rate of $48.1 \%$, was the most preva lent parasite in the IMIP patients, followed by Ascaris lumbricoides $(26.9 \%)$, hookworm $(6.4 \%)$, Strongyloides stercoralis $(4.5 \%)$ and Schistosoma mansoni $(1.3 \%)$. In contrast, the Cabo inhabitants, regardless of age, showed much higher prevalence rate of intestinal helminths. Hook worm infections, with a rate of $66.7 \%$, was the most prevalent one, followed by A. lumbricoides $(62.1 \%)$, T.trichiura $(60.1 \%)$, S. stercoralis $(9.6 \%)$ and S. mansoni $(9.6 \%)$. Two cases of Enterobius vermicularis and one case of Hymenolepis diminuta infections were also found in the Cabo inhabitants.

Test tube cultivation revealed that Necator americanus infection was much more common than of Ancylostoma duodenale in both areas $187.5 \%$ vs. $12.5 \%$ in the IMIP patients and $93.0 \%$ vs. $7.0 \%$ in the Cabo inhabitants). This procedure also demonstrated a high prevalence rate of $\mathbf{S}$. stercoralis infection in both IMIP patients $(4.5 \%)$ and Cabo inhabitants $(9.6 \%)$.

Prevalence of intestinal protozoa was sum marized in Table 4. Giardia lamblia infection $(26.3 \%)$ was the most prevalent one in the IMIP patients, followed by Entamoeba coli (17.3\%), Endolimax nana $(13.5 \%)$, Entamoeba histolyti-

TABLE 2

Prevalence of intestinal protozoa and helminths in the out-patients of IMIP hospital and the inhabi tants of Cabo City area

\begin{tabular}{|c|c|c|c|c|}
\hline & \multirow{2}{*}{$\frac{\text { IMIP patients }}{0-12 \mathrm{yrs}}$} & \multicolumn{2}{|c|}{ Cabo inhabitants } & \multirow[b]{2}{*}{ Total } \\
\hline & & $0-12$ yrs & 13 yrs $\leqq$ & \\
\hline $\begin{array}{l}\text { Total number of stools } \\
\text { examined }\end{array}$ & 156 & 170 & 289 & 459 \\
\hline $\begin{array}{l}\text { Number of positive cases for } \\
\text { parasitic infections }\end{array}$ & $111(71.2 \%)$ & $159(93.5 \%)$ & $263(91.0 \%)$ & $422(91.9 \%)$ \\
\hline Male & $58(68.2 \%)$ & $59(89.4 \%)$ & $104(92.9 \%)$ & $163(91.6 \%)$ \\
\hline Female & $53(74.6 \%)$ & $100(96.2 \%)$ & $159(89.8 \%)$ & $259(92.2 \%)$ \\
\hline $\begin{array}{l}\text { Number of positive cases for } \\
\text { helminthous infections }\end{array}$ & $92(58.9 \%)$ & $149(87.6 \%)$ & $242(83.7 \%)$ & $391(85.2 \%)$ \\
\hline $\begin{array}{l}\text { Number of positive cases for } \\
\text { protozoan infections }\end{array}$ & $66(42.3 \%)$ & $89(52.4 \%)$ & $151(52.2 \%)$ & $240(52.3 \%)$ \\
\hline
\end{tabular}

Values in parentheses represent the prevalence rate (\%) of each region. 


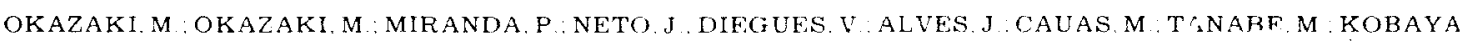
SHI. S: KANEKO, N : NAGAKUFA, K.: KOBAYASHI. M.: MOTTA. S.. TATENO. S. \& TAKEULHI. 7 - Parasito logical and serological sudies on anoebiasis and other intestmal parasitic infections in Recife and its suburban area. Northeast Brazil Rev. Inst. Med trop. Säo Paulo, 30(4): 313321,1988

TABLE 3

Prevalence of helminths in the out patients of IMIP hospital and the inhabitants of Cabo City area

\begin{tabular}{|c|c|c|c|c|}
\hline \multirow[t]{2}{*}{ Parasites } & \multirow{2}{*}{$\frac{\text { IMIP patients }}{012 \mathrm{yrs}}$} & \multicolumn{2}{|c|}{ Cabo inhabitants } & \multirow[b]{2}{*}{ Total } \\
\hline & & $0.12 \mathrm{yrs}$ & $13 \mathrm{yrs}$ & \\
\hline Ascaris lumbricoides & $42\left(26.9^{\prime},\right)$ & $121(71.1 \%)$ & $164(56.7 \%)$ & $285(62.1 \%)$ \\
\hline Trichuris trichiura & $75(48.1 \%)$ & $107(62.9 \% ;)$ & $169(58.5 \%)$ & $276(60.1 \%)$ \\
\hline Hookworm & $10 \quad 16.4^{r} ; j$ & $110(64.7 \%)$ & $196(67.8 \%)$ & $306(66.7 \%)$ \\
\hline Necator americanus & $714.5 \% 1$ & $95(55.9 \%)$ & $184(63.7)$ & $279(60.8 \%)$ \\
\hline Ancylostoma duodenale & $1\left(0.6^{\prime} ;\right)$ & $2 \quad(1.2 \%)$ & $4(1.4 \%)$ & $6(1.3 \%)$ \\
\hline unknown & $211.3 r i$ & $14(8.2 \%)$ & $7\left(2.4^{r i r}\right)$ & $21(4.6 \%)$ \\
\hline Strongyloides stercoralis & $7\left(4.5^{\prime},\right)$ & $18(10.6 \%)$ & $26 \quad 19.0 \%)$ & $44 \quad(9.6 \%)$ \\
\hline Enterobius vermicularis & 0 & $2(1.2 \%)$ & 0 & $2(0.4 \%)$ \\
\hline Schistosoma mansoni & $2\left(1.3^{\prime} ;\right)$ & $19(11.2 \%$ & $25(8.7 \%)$ & $44(11.2 \%)$ \\
\hline Hymenolep is diminuta & 0 & $1(0.6 \%)$ & 0 & $1(0.2 \%)$ \\
\hline
\end{tabular}

Values in parentheses represent the prevalence rate $(\%)$ of each region.

TABLE 4

Prevalence of intestinal protozoas in the out patients of IMIP hospital and the inhabitants of Cabo City area

\begin{tabular}{|c|c|c|c|c|}
\hline \multirow[t]{2}{*}{ Parasites } & \multirow{2}{*}{$\frac{\text { IMIP patients }}{0-12 \mathrm{yrs}}$} & \multicolumn{2}{|c|}{ Cabo inhabitants } & \multirow[b]{2}{*}{ Total } \\
\hline & & $\overline{0.12 \text { yrs }}$ & $13 \mathrm{yrs} \leqq$ & \\
\hline Giardia lamblia & $41\left(26.3 r_{i}\right)$ & $24(14.1 \%)$ & $23(8.0 \%)$ & $47(10.2 \%)$ \\
\hline Entamoeba coli & $27(17.3)$ & $74(43.5 \%)$ & $91(31.5 \%)$ & $165(35.9 \%)$ \\
\hline Entamoeba histolytica & $12(7.7 \%)$ & $18(10.6 \%)$ & $36(12.5 \%)$ & $54(11.8 \%)$ \\
\hline Entamoeba hartmanni & 0 & $7 \quad(4.1 \%)$ & $8(2.8 \%)$ & $15(3.3 \%)$ \\
\hline Endolimax nana & $21(13.5 \%)$ & $35(20.6 \%)$ & $57(19.7 \%)$ & $92\left(20.0^{\%}\right)$ \\
\hline Chilomastix mesnili & $1\left(0.6^{c} i\right)$ & 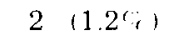 & $10(3.5 \%)$ & $12(2.6 \%)$ \\
\hline Iodamoeba buetschlii & $2(1.3 \%)$ & $17(10.0 \%)$ & $26 \quad(9.0 \%)$ & $43 \quad(9.4 \%)$ \\
\hline Trichomonas hominis & $4\left(2.6^{\prime \prime}\right)$ & $7(4.1 \%)$ & $14(4.8 \%)$ & $21(4.6 \%)$ \\
\hline Isospora belli & $2(1.3 \%)$ & 0 & 0 & 0 \\
\hline Balantidium coli & 0 & 0 & $2(0.7 \%)$ & $2 \quad 10.4 \%$, \\
\hline
\end{tabular}

Values in parentheses represent the prevalence rate $(r)$ of each region.

ca $17.7 \%$, and Trichomonas hominis $(2.6 \%)$. Chilomastix mesnili cone case). Iodamoeba buetschlii ( 2 cases) and Isospora belli ( 2 cases) were also found. In the Cabo inhabitants. F. coli infection ( $35.9 \%)$ was the most prevalent. followed by E. nana $(20.0 \%)$, E. histolytica $(11.8 \%)$. G. Iamblia $(10.2 \%)$. I. buetsehlii $(9.4)$, T. hominis $(4.6 \%)$ and Entamoeba hartmanni $(3.3 \%)$
Trophozoite of Balantidium coli was also found in two primary school pupils in Cabo.

Multiple infection was observed at $75.8 \%$ of the IMIP patients with parasitic infection, while a higher rate of multiple infection $(84.6 \%)$ was demonstrated in the Cabo inhabitants (Fig. 1 ). 
OKAZAKI, M.: OKAZAKI, M.: MIRANDA, P : NETO, J : DIEGUES, V.: ALVES, J.: CAUAS. M.: TANABE, M KOBAYA SHI. S.: KANEKO. N.: NAGAKURA, K.: KOBAYASHI, M : MOTTA. S.: TATENO, S. \& TAKEUCHI, T. - Parasito logical and serological studies on amoebiasis and other intestinal parasitic infections in Recife and its suburban area, Northeast Brazil. Rev. Inst. Med. trop. Sào Paulo, 30 (4): 313 321, 1988.
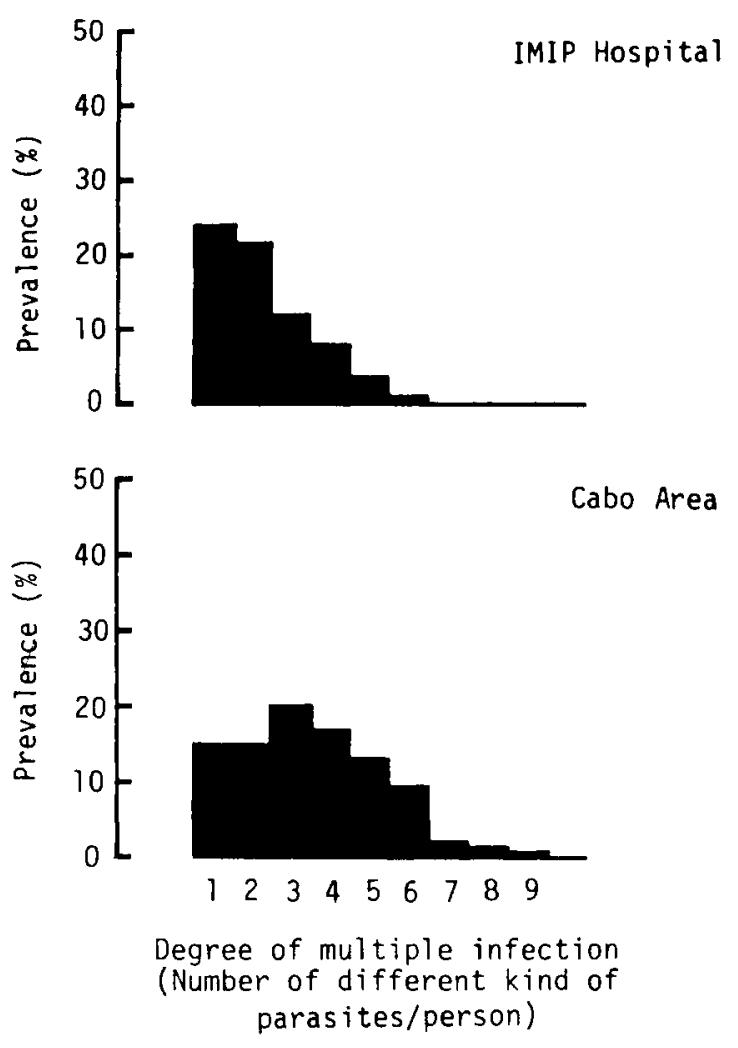

Fig. 1 - Prevalence rate of multiple infection of intestinal para sites in the out patients of IMIP hospital and inhabitants of Cabo City area.

TABLE 5

Result of serological examination for amoebiasis by GDP and ELISA on the out patients of IMIP hospital and the inhabi tants of Cabo City area

\begin{tabular}{|c|c|c|c|c|c|c|}
\hline & \multirow{2}{*}{ Cyst } & \multicolumn{2}{|c|}{ GDP } & \multicolumn{2}{|c|}{ ELISA } & \multirow{2}{*}{ Total } \\
\hline & & + & - & + & - & \\
\hline \multirow{3}{*}{$\begin{array}{l}\text { IMIP } \\
\text { patients }\end{array}$} & + & 0 & 12 & 2 & 10 & 12 \\
\hline & - & 0 & 144 & 15 & 129 & 144 \\
\hline & Total & 0 & 156 & 17 & 139 & 156 \\
\hline \multirow{3}{*}{$\begin{array}{l}\text { Cabo } \\
\text { inhabitants }\end{array}$} & + & 0 & 54 & 7 & 47 & 54 \\
\hline & - & 0 & 405 & 8 & 397 & 405 \\
\hline & Total & 0 & 459 & 15 & 444 & 459 \\
\hline \multirow{3}{*}{ Total } & + & 0 & 66 & 9 & 57 & 66 \\
\hline & - & 0 & 549 & 23 & 526 & 549 \\
\hline & Total & 0 & 615 & 32 & 583 & 615 \\
\hline
\end{tabular}

Cysts of E. histolytica were found at $7.7 \%$ of the IMIP patients and $11.8 \%$ of the Cabo inha bitants as mentioned above; thus, stool examination indicated that the overall prevalence rate was $10.7 \%$. As shown in Table 5 , moreover, all sera (615 samples) obtained from both IMIP patients and Cabo inhabitants were examined se rologically by GDP. No positive reaction was observed in all of the sera examined, although three positive control sera, obtained from Japanese patients with confirmed amoebic liver abscess, formed 3 to 5 clear precipitation lines

In addition to GDP, we tried to establish an ELISA to detect antibody against E. histolytica antigen. In the primary experiment, as shown in Fig. 2, the specificity and sensitivity of our ELISA was evaluated. Serum samples from 17 cases with confirmed amoebiasis and 30 healthy Japanese students were diluted 200 times and examined by our ELISA method. Since mean absorbance value of the negative controls was $0.033 \pm 0.012$, the upper limit (cut-off value) of the absorbance of negative controls was calcu lated to be 0.1 by multiplying the mean absorbance value by 3 . The absorbance of positive control sera isolated from 17 Japanese patients with amoebic liver abscess and colitis was far above this value $(0.280$ to 1.500$)$. Hence, the absorbance of 0.1 was considered to be reasonable as

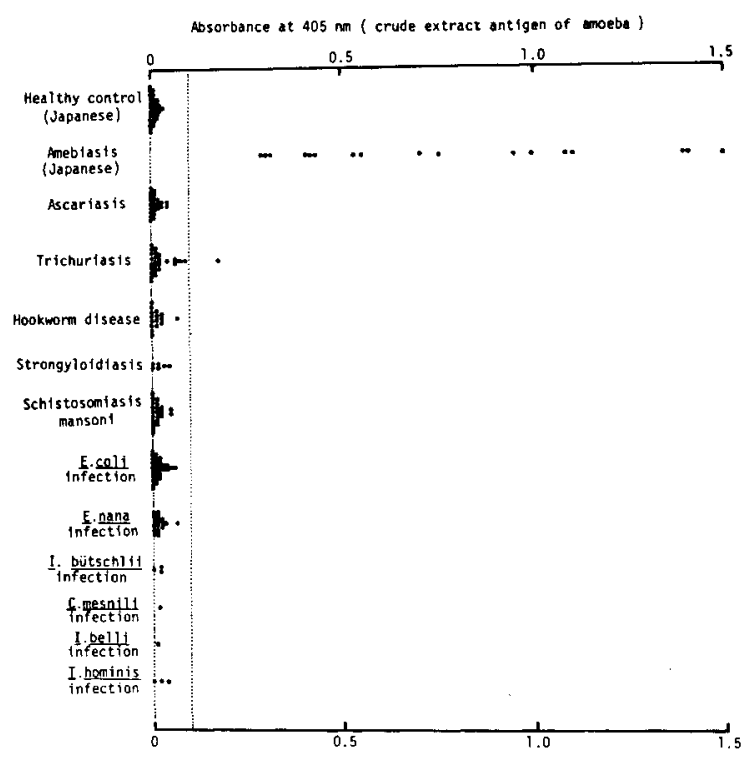

Fig. 2 - Result of cross reactivity of sera isolated from the out patients of IMIP hospital and inhabitants of Cabo City area. who were infected with single or a few species of parasites. with Entamoeba histolytica antigen on ELISA 
OKAZAKI, M.: OKAZAKI, M.: MIRANDA, P.:NETO, J : DIEGUES, V : ALVES, J : CAUAS, M : TANAB M M.: KOBAYA SHI. S.; KANEKO. N.; NAGAKURA, K.; KOBAYASHI, M.; MOTTA, S.; TATENO, S. \& TAKEUCHI, T. - Parasito logical and serological studies on amoebiasis and other intestinal parasitic infections in Recife and its suburban area, Northeast Brazil. $\quad$ Rev. Inst. Med. trop. Sảo Paulo, 30 (4): 313321,1988

the upper limit of negative sera. Fig. 2 also showed that serum samples isolated from the IMIP patients infected with various parasites did not show a positive reaction except for one case with trichuriasis. From this observation, it is likely that there are scarcely cross reactions between E. histolytica antigen and sera isolated from various parasitic infections, and that our ELISA seems to be specific and have a sufficient sensi tivity on epidemiological survey of amoebiasis.

As shown in Table 5 , the positive reaction of ELISA was observed in 32 out of 615 sera exa mined. Nine $(13.6 \%)$ out of 66 sera isolated from the IMIP patients and the Cabo inhabitants, who discharged E. histolytica cystis in their stools, exhibited positive reaction on ELISA, while twenty-three sera $(4.1 \%$ ) out of 549 cyst-ne gative subjects were also judged positive on ELI SA.

Ninety eight stool specimens were inocula ted into Balamuth medium and then trophozoite growth was examined. No trophozoite growth was observed in all stools examined although 16 out of 98 stools were positive for E. histolytica cysts.

\section{DISCUSSION}

Our present investigation indicates that the out-patients of IMIP hospital and the inhabitants of Cabo City area were heavily infected with intestinal parasites. The overall prevalence rate of the IMIP patients and Cabo inhabitants were 71.2 and $91.9 \%$, respectively, which are much higher than those of central and southern Brazil $^{7}, 18,27,28$. There was significant difference in the prevalence rate of hookworms, A. lumbricoides and S. mansoni, but not of T. trichiura, between the IMIP patients (urban area) and the Cabo inhabitants (rural area). The higher prevalence of these parasites in such rural sectors sug. gests that these infections are a particular problem in agricultural areas with abundant water resource, which play an important role in main taining these parasitic infections.

Test tube cultivation method revealed that approximately 87 to $93 \%$ of the IMIP patients and Cabo inhabitants, who discharged hook worm eggs, were infected with $\mathbf{N}$. americanus.
Using the same technique, ASAMI et al. ${ }^{1}$ already demonstrated that prevalence of $\mathbf{N}$. americanus in the patients of UFPE hospital was much higher than that of A. duodenale. Since MARZOCHI \& CHIEFFI ${ }^{14}$ also demonstrated higher pre valence rate of $\mathbf{N}$. americanus in the inhabitants of Parana State. southern Brazil, it seems likely that $\mathbf{N}$. americanus is the main hookworm spe cies in Brazil. This technique also demonstrated the high prevalence rate of $\mathbf{S}$. stercoralis in both areas. In Cabo area, approximately $10 \%$ of the inhabitants were infected with this parasite. Since test tube cultivation method already showed $5.1 \%$ of patients in the UFPE hospital were infec ted with $\mathbf{S}$. stercoralis ${ }^{1}$, $\mathbf{S}$. stercoralis infection appears still cormmon in Recife area.

S. mansoni egg was detected in only 2 out patients of IMIP hospital, whereas approxima tely $10 \%$ of the inhabitants in Cabo City area were found positive for the eggs by stool examination. An epidemiological study on schistosomiasis in São Lourenço village in Pernambuco, in 1975 and 1979, ASAMI et al. ${ }^{2}$ detected schistosome eggs from over $40 \%$ of primary school pupils. BARBOSA 4 also demonstrated high prevalence rate of $\mathbf{S}$. mansoni infection in the primary school pupils in Pernambuco State. Schistosomiasis is, therefore, still considered to be one of the most important parasitic diseases in the rural sector of Pernambuco State.

Our present examination also demonstrated a high prevalence rate of intestinal protozoa. In the rural area of Pernambuco, the prevalence rate of all intestinal protozoa except for E. histolytica reported here were much higher than those published before ${ }^{2,7,18}$. The high prevalence rate of intestinal protozoa, including pathogenic and non-pathogenic, is considered to be dependent on the contamination of drinking water and food with protozoan cyst in accordance with incomplete stool disposal by poor sanitary facilities. Among these intestinal protozoa, G. lamblia and E. histolytica were considered impor tant in this area in respect to their pathogenicity. The difference in prevalence rate of $\mathbf{G}$. lamblia between the IMIP patients and the Cabo inhabitants is interesting. Although this may be at least partially dependent on the difference in age distribution between these two groups, there was still a difference in the prevalence rate of 
OKAZAKI, M.; OKAZAKI, M.; MIRANDA, P.: NETO, J.: DIEGUES, V.; ALVES, J ; CAUAS, M : TANABE, M.. KOBAYA SHI, S.; KANEKO, N.; NAGAKURA, K.; KOBAYASHI, M.; MOTTA, S.; TATENO, S. \& TAKEUCHI, T. - Parasito logical and serological studies on amoebiasis and other intestinal parasitic infections in Recife and its suburban area. Northeast Brazil. Rev. Inst. Med. trop. Säo Paulo, 30 (4): $313321,1988$.

G. Iamblia in comparing the same age groups from two areas. Therefore, the direct transmis. sion (person to person) $)^{5}$, in large communities such as school and/or playground. may be worth consideration for prevalence of this parasite

Sixty-six out of 615 persons were demontrated to be positive for E. histolytica cyst by stool examination. It is, therefore, assumed that $\mathbf{E}$. histolytica infection still distributed widely in Recife area. To estimate the reliable morbidity of invasive amoebiasis, serological tests were employed. As shown in Table 5, none of the sera was positive on GDP although these specimens included sera from the subjects with E. histolytica cyst in their stools and/or with various intestinal symptoms. In the previous studies ${ }^{13}$. 19. ${ }^{26}$ GDP was considered to be one of the most reliable serological tests for diagnosis of amoebiasis, since it is well correlated with the clinical course of symptomatic amoebiasis. Our observation, therefore, may be explained as follows: there was no case with invasive amoebiasis among the subjects examined in this study; rather, all of them with cyst in stool may be asymptomatic cyst carrier according to the concept established by SARGEAUNT and his colleagues ${ }^{22 .}{ }^{23}$. 24 . In other words, avirulent strains of E. histolytica primarily distribute around Recife and its suburban area. This speculation is supported by pre vious observation that the incidence of amoebic liver abscess at autopsy was extremely low ${ }^{20}$. And by our preliminary finding that neither GDP nor ELISA detected anti-amoebic antibody in serum samples isolated from 20 or more hospitalized patients who were clinically diagnosed to have amoebic liver abscess or colitis.

As shown in Fig. 2, evaluation of ELISA me thod as a tool for sero-diagnostic method indicates that this method appears specific to E. histolytica antigen. However, ELISA could detect anti amoebic antibody in 9 out of 66 persons with E. histolytica cyst in their stools and in 23 of 549 persons without cyst. Recently OKUSAWA et al. ${ }^{17}$ reported that ELISA could demonstrate an IgG class anti-amoebic antibody over $80 \%$ of sera isolated from the asymptomatic cyst car rier. The difference between these two observa tions can be explainable by the difference in em ployed ELISA method. To characterize the epi demiological feature of amoebiasis in northeast Brazil, an extensive epidemiological survey utili- zing serological and parasitological techniques as well as an establishment of axenic or monoxenic strain of E. histolytica isolated from this region seems to be absolutely necessary.

\section{RESUMO}

Estudos sorológicos e parasitológicos na Amebíase em outras infecções parasitárias intesti. nais em Recife e áreas circunvizinhas, nordeste do Brasil

Exames parasitológicos foram realizados em 187 pacientes do Hospital do IMIP e 464 habitantes de vários vilarejos no município do Cabo, $50 \mathrm{Km}$ à sudeste de Recife, durante os meses de abril a agosto. Aproximadamente $71 \%$ dos pacientes examinados do IMIP e $92 \%$ dos exami nados do Cabo apresentavam-se infectados com, no mínimo, uma espécie de parasita intestinal.

Houve uma diferença minima na taxa de prevalência de Trichuris trichiura entre as duas áreas, entretanto a prevalência de Ascaris lumbricoides, família Ancylostomidae, Strongyloides stercoralis, Schistosoma mansoni e Entamoeba histolytica foi maior entre os habitantes do Cabo. Somente a Giardia lamblia apresentou uma taxa de prevaléncia maior nos pacientes do IMIP.

O cultivo em tubo de ensaio revelou que a prevalência do Necator americanus em relação a do Ancylostoma duodenale era muito maior em ambas as áreas e que a do S. stercoralis entre os pacientes do IMIP e dos habitantes do Cabo era, respectivamente, $4.5 \%$ e $9.6 \%$

$A$ amebíase foi verificada através de exames sorológicos, imunodifusāo em gel (GDP) e enzima imunoensaio (ELISA), usando como antíge. no extrato bruto preparado a partir dos trofozoi tos de E. histolytica (cepa HM-1: IMSS), realizados em 615 soros, onde nenhuma reação positiva aparente foi observada através da imunodifusão, contudo foram observados resultados positivos em 32 dos 615 casos através da enzima imunoensaio.

\section{ACKNOWLEDGEMENT}

This study was supported by Japan Interna tional Cooperation Agency (JICA), Tokyo, Ja pan. 
OKAZAKI. M.: OKAZAKI, M.: MIRANDA. P.: NETO, J.: DIEGUES, V.; ALVES. J.: CAUAS, M.; TANABE, M.; KOBAYA SHI, S.: KANEKO, N.: NAGAKURA, K : KOBAYASHI, M.: MOTTA, S.: TATENO, S. \& TAKEUCHI, T. - Parasito logical and serological studies on amoebiasis and other intestinal parasitic infections in Recife and its supurban area, Northeast Brazil. Kev. Inst. Med. trop. Sáo Paulo. 30 (4): $313321,1988$.

\section{REFERENCES}

1. ASAMI, K.; ENOMOTO, Y. \& MIURA, S. - Infestaçäo por ancilostomideos e strongyloides em Pernambuco. In quérito baseado na identificaçào das larvas. Rev. Inst. Med. trop. S. Paulo, 12: $31-35,1970$

2. ASAMI, K.; MIURA, S.; YOKOGAWA. M.; OYA, H.; AO KI, T, \& KOJIMA, S. - Prevalence of parasites in school children of Sào Lourenço Village. Pernambuco, Brazil in 1975 and 1979. In: REPORT OF OVERSEA S SCIENTIFIC EXPEDITION. Clinico-pathological and immunological investigations on schistosomiasis mansoni in north-east Brazil. Tokyo, Keio University, 1980. p. 17-28.

3. BALAMUTH, W. - Improved egg yolk infusion for cultiva tion of Entamoeba histolytica and other in testinal proto zoa. Amer. J. clin. Path., 16: 380 384, 1946

4. BARBOSA, F. S. - Cross-sectional studies on Schistosoma mansoni infection in nor theastern Brazil. Ann. tron. Med. Parasit., 69: 207-216, 1975

5. BLACK, R. E.: DYKES, A. C.: SINCLAIR, S. P. \& WELLS J. G. - Giardiasis in day-care centers: Evidence of person to person transmission. Pediatrics, 60: 486.491, 1977.

6 DIAMOND, L. S.; HARLOW, D. R. \& CUNNICK, C. C - A new medium for the axenic cultivation of Entamoeba histolytica and other Entamoeba. Trans. roy. Soc. trop. Med. Hyg., r2: 431-432, 1978.

7 DIRECEU, P. P. C. - A esquistossomose em área Jitora nea Sul do Estado de Pernambuco. Recife. Fundacào Os waldo Cruz, Centro de Pesquisas Aggeu Magalhāes, 1978

8. HARADA. Y. \& MORI. O. - A simple culture method of Ancylostoma duodenale. Med. Biol, 20:65.67, 1951.

9. JUNIPER JR, $\mathrm{K}$ : : WORRELL, C. L : MINSHEW, M. C. ROTH, L. S.; CYPERT, H. \& LLOYD, R. E. - Serologic diagnosis of amoebiasis. Amer. J. trop. Med. Hyg., 21: $157-168,1972$

10. KRUPP, I. M. - Comparison of counterimmunoelectro phoresis with other serologic tests in the diagnosis of amoebiasis. Amer. J. trop. Med. Hyg., 23: 27 30, 1974

11. LENNETTE, E. H.; SPAULDING. E. H. \& TRUANT, J P. - Manual of clinical microbiology. 2nd. ed. Washing ton, American Society for Microbiology, 1974. p. 970

12. LOWRY, O. H.: ROSEBROUGH, N. J.; FARR, A. L. \& RANDALL, R. J. - Protein measurement with the Folin phenol reagent. J. biol. Chem., 193: 265275, 1951

13. MADDISON, S. E. - Characterization of Entamoeba histolytica antigen-antibody reaction by gel diffusion. Exp. Parasit., 16: 224 235, 1965

14. MARZOCHI, M. C. A. \& CHIEFFI, P. P. - Estudos dos fatores envalvidos na disseminaça de dois enteropara sitas. IV. Distribuiçáo do Necator americanus e do Ancy. lostoma duodenale na populacāo periurbana e rural do municipio de Londrina. Paraná, Brasil. Rev. Inst. Med. trop. S. Paulo, 20: $3640,1978$.

15. MATSUDA, H.: TANAKA, H: BLAS, B. L.; NOSENAS, J. S.: TOKAWA, T. \& OHSAWA, S. - Evaluation of ELISA with ABTS, 2,2'-azino-di (3 ethylbenzthiazoline sulfonic acid, as the substrate of peroxidase and its application to the diagnosis of schistosomiasis. Jap. J. exp. Med., 54: $131-138,1984$.
16. MILGRAM E A HEALY G.K. \& KAGAN I G - Stu dies on the use of the indirect hemagglutination test in the diagnosis of amoebiasis. Gastroenterology, 50: $645 \cdot 649,1966$

17. OKUSAWA, E.; KOBAYASHI, S.; TAKEUCHI, T.; MAT SUDA. H. \& TANAKA. H. -- Evaluation of diagnostic va lue of ELISA in various types of amoebiasis. Jap. J. Parasit., 36 (suppl.): 113, 1987.

18. OLIVEIRA, M. R; BARBOSA, M. A.; SALATA, E.; SO GAYA, M. I. T. L.; SOGAYA, R. \& CORREA, F. M. A. - Prevalência de enteroparasitas na população urbana do 2: subdistrito de Botucatu. Rev. Saude Publ. (S. Pau. lo), 8: 213-234, 1974

19. PATTERSON, M.; HEALY, G. R. \& SHABOT, J. M Serologic testing for amoebiasis. Gastroenterology, 78 : $136-141,1980$

20. REY, L. - Entamoeba histolytica e amebiase (I) \& (II) In: REY, L. - Parasitologia. Rio de Janeiro, Guanabara Koogan, 1972. p. 240269

21. RITCHIE, L. S. - An ether sedimentation technique for routine stool examinations. Bull. U. S. Army med. Dep., 8: $326 \cdot 328,1948$

22. SARGEAUNT, P. G. - The reliability of Entamoeba histolytica zymodemes in clinical diagnosis. Parasit. Today, 3: 4043,1987

23. SARGEAUNT, P. G.: BAVEJA, U. K., NADDA, R. \& ANAND, B. S. - Influence of geographical factors in the distribution of pathogenic zymodemes of Entamoeba histolytica: identification of zymodeme XIV in India. Trans. roy. Soc. trop. Med. Hyg., 78: 96-101. 1984

24. SARGEAUNT, P. G.; WILliams, J. E. \& GRENE, J. D - The differentiation of invasive and non-invasive Entamoeba histolytica by isoenzyme electrophoresis. Trans. roy. Soc. trop. Med. Hyg., z2: 519-521, 1978.

25. TAKEUCHI, T \& KOBAYASHI S. - Serological test for amoebiasis with special reference to gel diffusion preci piting test. Igakuno-ayumi, 115: 53.58, 1980.

26. TAKEUCHI, T; KOBAYASHI, S \& TATENO, S - Eva luation of serologic testings of amoebiasis. Jap. J. Parasit., 34 (suppl): 75, 1985.

27. VINHAS, C. -- Incidéncia de ancilostomideos, ascaris e trichiuris no Brasil. Rev, bras. Malar., 21: 549 557, 1969

28 VINHAS C - Incidéncia no Brasil de helmintos transmi tidos pelo solo; rotina coproscopica do ex departamento nacional de endemias rurais. Rev. bras. Malar., 23: 3-17. 1971.

29 VOLLER A: BIDWELL, D. E \& BARTLETT, A. - The enzyme linked immunosorbent assay (ELISA). In: A guide with abstracts of microplate applications. Aiexandria, Virginia, Dynateck Lab., 1979. p. 125

30. YAMAGUCHI $\mathbf{S}$. KANO $\mathrm{K}$ \& SHIROISHI $\mathrm{Y}$ - . COM munity health problems in Latin America: a statistical analysis and an appraisal of health indices in northeast Erazil. Latin Amer. Studies, 4: 105-129, 1982

Recebido para publicaçâo em 24/4/1988 